\title{
An Overview of Innovation Intensity in the Indigenous Oilfield Services Firms in Nigeria
}

\author{
Jege de O. O. ${ }^{1, *}$, Ilori M. O. ${ }^{2}$, Sonibare J. A. ${ }^{3}$, Oluwale B. A. ${ }^{2}$, Siyanbola W. O. ${ }^{1}$ \\ ${ }^{1}$ National Centre for Technology Management, Obafemi Awolowo University, Ile-Ife, Osun State, Nigeria \\ ${ }^{2}$ African Institute for Science Policy and Innovation, Obafemi Awolowo University, Ile-Ife, Osun State, Nigeria \\ ${ }^{3}$ Department of Chemical Engineering, Obafemi Awolowo University, Ile-Ife, Osun State, Nigeria
}

\begin{abstract}
The study examined the types and intensity of innovations in the indigenous Nigeria's oil and gas servicing sub-sector. The study used primary and secondary data sources, 100 firms were purposefully selected and sampled, focusing on the period between 2001 and 2010. A total of 400 questionnaires were admin istered of which $70 \%$ were returned and found suitable for analysis. The responses were aggregated such that the unit of analysis was the firm. Secondary data were sourced from the internet and other published sources. The data so obtained were analy zed using descriptive and inferential statistics. Of the 4 types of innovation that the study exa mined, organizat ional innovation was the most prevalent (46\%) while diffusion-based innovation was least (10\%). Product and process innovations were implemented, respectively, by $17 \%$ and $22 \%$ of the firms. Innovation intensity was low: only two patents were granted to the firms within the period 2007-2010, level of organizational learning was low, the number of R\&D staff was low while the impact of innovation on firms' performance was expressed in increase in profit, process improvement and new product development. In conclusion, our study found out that the overall innovation capability of the firms was expressed in organizational innovations.
\end{abstract}

Keywo rds Intensity, Innovation, Indigenous Oil Servicing Firms, Organizational Learning

\section{Introduction}

Science and technology (S\&T) is critical to the economic growth and development of any nation. Indeed, the extent to which new knowledge is generated and innovation used is what distinguishes developing countries from developed ones. The difference between developing countries and emerging economies, such as Brazil, China and India that are fast becoming industrialized can similarly be attributed to difference in scientific research and innovation[13]. S\&T has also been identified to be critical to progress of industrialization in our modern knowledge-driven world economy. Therefore, many countries now devote an increasing proportion of their capability and resources to S\&T and to research and development (R\&D) in order to achieve competitive advantage.

Researchers in the area of sustainable competitive advantages have come to the conclusion that the only thing that endows a competitive edge on an organization or a nation is what it knows, how it uses what it knows and how fast it can know something new $[7 ; 10 ; 18]$. In other words, the cause of the competitive gap between nations of the north

* Corresponding author:

jegede.seye@yahoo.com (Jegede O. O.)

Published online at http://journal.sapub.org/mm

Copyright (C 2012 Scientific \& Academic Publishing. All Rights Reserved and south is knowledge[18]. The payback of science and technology are derived through the invention and application of scientific and technological knowledge to create new products and processes and add value to existing products and processes. Hence, with or without technology transfer, late comer economies - like Nigeria - do not automatically benefit from the increasing global pool of technologies [23].

In developing countries, innovation is seen as a process of adoption, absorption and diffusion of traditionally available technology[11]. It is therefore important for firms in the indigenous oil and gas industry in Nigeria to develop the capability to explo it the locally available technology to gain competitive advantage. This capability is embedded in the set of skills and competences which the firm possesses and/or can exploit to manage change[15].[22] defined innovation capability as the skills, knowledge, resources, creativity and attitude needed to continuously generate and translate ideas and change into marketable new or significantly improved devices, products, processes and services. Innovation is very essential for the Nigerian indigenous oil and gas firms' growth and also for these firms to compete with the foreign firms with in the industry[8; 21; 22].[22] linked innovation with economic growth. A nation's economic growth is the nation's increasing capacity, to produce more and better goods and services to its population.

\section{Methodology}


The study, which used primary and secondary data sources, was based on a sample of the indigenous oil and gas servicing firms in Nigeria. 100 firms were purposefully selected and sampled, focusing on the period between 2001 and 2010. Four types of questionnaire were administered in the firms. This was supplemented with shop-floor observations and interviews. The questionnaires elicited information on the firms' innovation activities and the factors that influenced these. A total of 400 questionnaires were administered on heads of Production, Engineering, Finance and Administration in the firms out of which $70 \%$ were returned and found suitable for analysis. The responses were aggregated such that the unit of analysis was the firm. Secondary data were sourced from the internet and other published sources. The data so obtained were analysed using descriptive and inferential statistics.

\subsection{Four Types of Innovation}

To measure the technological innovation, this study considered 4 types of innovation as outlined below.

i. Product innovation was measured via three proxy variables, one of which is similar to those used in many previous studies $[19 ; 14]$. The first variable indicated whether or not the firm developed a new product during the reference period. The next two variables measured whether or not the firm introduced a new product to the market or modified an existing one.

ii. Process innovation was measured via three proxy variables indicating whether the firm developed, introduced a new process in its production activities or modified an existing one[19; 25].

iii. Organizational innovation was captured with four variables drawn from[25]: changes in quality controls; maintenance routines, waste management procedures and reverse engineered any product or process.

iv. Diffusion-based innovation is considered to be unique in the sense that it is particularly important in the developing country context. According to[17], in developing countries, technology transfer from multinational corporations and from abroad is a fundamental source of innovation; and acquisition of embodied technology (equipment) for both product and process innovation is a major component of innovation. The crucial importance of capital goods as a source of innovation even in developed countries is confirmed by a survey of European enterprises, which shows that 50 per cent of total innovation expenditure is embodied in plant, machinery and equipment purchased by industrial firms, with own R\&D accounting for just 20 per cent[24]. This innovation type was measured through two simple binary variables: the acquisition of product licence and/or process licence. Whether or not a firm uses technology licensed from a foreign owned company or enters into a joint venture has been found to be important for firm growth[6].

\subsection{Extent of Innovation}

The intensity of innovation was measured using extent of innovation. The descriptive statistics on the extent of innovation within the indigenous oil and gas servicing firms was measured by the four variables as listed below:

i. The numbers of patents requested by the firms and the number of patents granted to the firms with in the period 2001-2010

ii. Number of R\&D staff working in the firms within the period 2007-2010

iii. The intensity of organisational learning within the period 2007-2010

iv. The impact the innovation activities on firms' performance indicators within the period 2007-2010

\section{Results and Discussion}

\subsection{Prevalence of Technological Innovations in the Surveyed Firms}

The study considered the prevalence of different types of technology-based innovative activities in the sub-sector. Table 1 shows the statistics on the prevalence of each type of technological innovation found within the indigenous oil and gas industry. The Innovation index for product innovation was 0.17 , process innovation was 0.22 , organizational innovation was 0.46 and diffusion-based innovation was 0.10 . On the average, $21 \%$ of the firms were innovation-active during the reference period.

As shown in Table 1 and 2, the prevalence of technological innovations was low except for organizational innovation which seems to be common to most of the firms. The prevalence of product innovation is observed to be low. This is probably due to the fact that the resource required to implement these changes might not be available to many of the firms. The main product innovation in the surveyed firms was expressed in the introduction of new products rather than improving the already existing product and developing new products. This is might be due to the fact the firms need to widen the range of their services.

On the contrary, the firms did not introduce new processes; they concentrated on improving the existing process. This may be because process innovation in the oil and gas servicing firms was mainly expressed in the purchase, mastery and efficient use of new equipment. The cost of acquiring and deploying new machinery is high and interviews conducted in the field showed that most firms cannot easily afford it; it has to be strategically planned and budgeted for.

The prevalence of organizational innovation was found to be highest and this could be because organizational innovation costs less to carry out. This suggests that organizational changes are at the heart of the innovation processes in the indigenous oil and gas servicing firms. This agrees with the study of[5] on the innovation capability in the cable manufacturing sub-sector. These changes, like[14] argued, are typically expressed in business practices and 
workp lace organization that are new to the firm and occur as a result of strategic management decisions. The intensive prevalence of organizational innovation within our developing country context is not surprising because organizational changes are less risky and consume much less resources compared to other types of innovations. The firms introduced maintenance routine to ensure good performance and the long time of their machinery. They introduced quality control to ensure the effectiveness and efficiency of their tools, equip ments and machinery.

Also, Table 1 shows that the performance of the firms in diffusion-based innovation was relatively poor. Diffusion-b ased innovation was found to be the lowest among the four types of innovation considered in th is study (Table 1). Th is is because almost all the firms in the industry are all SMEs that are mostly confronted by several resource constraints. It is therefore difficult for them to procure licenses to use the newest technologies already discovered, protected and used in technologically advanced nations. Low levels of absorptive capacities may also expla in this situation[20]. It is important to note here that although purchase of new machinery/equipment is included in the concept of diffusion-based innovation, the index constructed eventually only included product and process licensing (Table 2). This happened because most of the firms were reluctant to volunteer information on their purchase of equipment. The firms that have been able to do this are those which are affiliated to foreign firms and individuals. From the survey, it was found out that there were two firms using licenses for product technology and one of the two firms obtained the license from a foreign firm while the other firm obtained the license from a foreign university. Also three firms use license for process technology with two of the firms obtaining the license from a foreign firm while the other obtained the license from a Nigerian firm. Only a quarter of the surveyed firms developed or applied or modified versions of product and/process technology, About $31 \%$ of these developed new/modified versions of the product or process on their own while $69 \%$ did through partnership with their licenser.

Table 1. Innovation indices for the innovation types

\begin{tabular}{cc}
\hline Innovation types & Innovation Index \\
\hline Product Innovation & 0.17 \\
Process Innovation & 0.22 \\
Organisational Innovation & 0.46 \\
Diffusion-based Innovation & 0.10 \\
\hline
\end{tabular}

Source: Field survey, 2011

Legend: $0.00-0.40$ Low, $0.40-0.60$ Medium, $0.60-1.00$ High

\subsection{Intensity of the Innovations}

The evaluation of the intensity of innovation within the sub-sector was carried out by considering the extent of innovation among the firms.[14] and[25] identified a broad range of activities that a firm could undertake to innovate. These activities as considered in this study are summarized in Table 2. The more of these activities that a firm is posited to implement, the stronger the firm is said to be and by extension, the broader the range of innovation within an industry, the more dynamic the industry would be. For instance, a higher level of uncertainty and competitiveness is very likely to be experienced within an industry where firms have comparable tendencies to develop new products, modify existing ones, make changes in their processes and approach the market in an innovative manner, among other innovative activities.

Table 2. Prevalence of innovation in the indigenous oil and gas servicing firms in Nigeria

\begin{tabular}{ccc}
\hline Product Innovation & Started but later abandoned (\%) & Initiated and completed (\%) \\
\hline Introduced new product & 1.5 & 30.9 \\
Improved existing product & 0 & 14.9 \\
Developed new product & 3 & 1.5 \\
\hline Process Innovation & Started but later abandoned (\%) & Initiated and completed (\%) \\
\hline Introduced new process & 3 & 20.9 \\
Improved existing process & 3 & 30.9 \\
Developed new process & 6 & 1.5 \\
\hline Organizational Innovation & Started but later abandoned(\%) & Initiated and completed (\%) \\
\hline Introduced quality control & 5.9 & 39.7 \\
Introduced maintenance routine & 8.7 & 52.2 \\
Introduced waste management procedure & 13.2 & 33.8 \\
Reversed engineering of any product/process & 22.4 & 9 \\
\hline Diffusion-based Innovation & & 2.9 \\
\hline Licensing contract for product technology & & 4.5 \\
Licensing contract for process technology & & 24.6 \\
Modified versions of product/process technology & & Initiated and completed (\%) \\
\hline
\end{tabular}

Source: Field survey, 2011 


\subsubsection{Number of Patents Requested by and Granted to the Firms}

The patent propensity rate is a potentially valuable indicator for both innovative activities and appropriation conditions as shown in table 3.

Table 3 shows the intensity of innovation is low as far as patenting is concerned. The firms have not really invented new technologies on their own as only two out of the nine patents that were applied for were granted to the seventy firms that were surveyed within the period 2001-2010.

\subsubsection{Number of R\&D Staff in the Work Force}

The trend in literature showed that it is not innovation input (Research and Development) but innovation output that increases productivity[12; 1]. However, firms invest in research in order to develop process and product innovation which in turn may contribute to their productivity and other economic performances. This study found out that one-third of the firms were involved in research and development activities but results of the research and development have not really translated into innovation (Table 4).

The data collected also showed that only $14 \%$ of the firms have research and development department as a separate technical department.

\subsubsection{Intensity of Organizational Learning}

Table 5 shows the various trainings the surveyed firms underwent within the period 2007-2010.

There are three main components of human capital: early ability (whether acquired or innate); qualifications and knowledge acquired through formal education; and skills, competencies and expert ise acquired through training on the job. The concept of human capital arose from a recognition that an individual's or a firm's decision to invest in human capital (i.e. undertake or finance mo re education or training) is similar to decisions about other types of investments undertaken by the individuals or firms. Human capital investments involve an initial cost (tuition and training course fees, forgone earnings while at school and reduced wages and productivity during the training period) which the individual or firm hopes to gain a return on in the future (for example, through increased earnings or higher firm productivity).

As with investments in physical capital, this human capital investment will only be undertaken by the wealth maximizing individualor firm if the expected return fro $m$ the investment (or 'net internal rate of return') is greater than the market rate of interest.

The firms surveyed did not engage well enough in organizational learning as less than a quarter of the sampled firms engaged in the different courses except for ICT in 2007. The rationale for this anomaly could be attributed to the fact that ICT and soft engineering services were diffused to the indigenous Nigerian oil and gas servicing firms between 2004 and 2006 as a result, many of the firms incorporated the use of ICT in their organizational routine and it was this that accounted for the 0.1 diffusion-based innovation index recorded in this study. Organizational learning theory suggests that innovation is an interactive learning process involving the generation, adoption, implementation and incorporation of new ideas and practices internally and externally[9]. The outcome of organization learning thus generates the knowledge and skill needed for firms to select, acquire, maintain, adapt, improve and develop competitive capabilities[7]. Such knowledge and capabilities further prepares the firms to better understand, evaluate and explo it external knowledge in the future[4]. More recent theories of open innovation further elaborates on the use of both internal and external ideas and paths to market, which increases the number of possible innovations and the ways that firms can capitalize on these innovations [2; 3]. The majority of the firms underwent organizational learning at some point in the reference period, the effect of this training is not really felt as the prevalence all the innovation types identified as relevant to this study were low except for organizational innovation. This could be a result of poor absorptive capacity which is usually due to the educational level of the employees or lack of machinery and tools to practice new knowledge or probably the innovations/technologies used by the foreign firms have been protected and probably the indigenous firms do not have funds to procure their licenses.

\subsubsection{Impact of the Innovation on Firms' Performance}

It is well acknowledged that technical change and innovation are major drivers of competitive advantage and economic growth. The contribution of technical change to the indigenous oil and gas servicing firms' competitive advantage is estimated by an array of indicators as expresses in table 6.

The impact of innovation activities of the indigenous oil and gas firms was given by: increase in the firm' process improvement as well as new product development and profit. The innovation activities didn't increase the market share of the indigenous oil and gas servicing firms above 31\% (Table 6) and this agrees with work of[16] which posited that the local content in the oil and gas industry is below $40 \%$. Also, the organizational routine of the indigenous oil and gas servicing firms are quite similar and since innovation in the industry is quite low, there has been no major diversification in the various services offered by the indigenous firms as most of the firms introduces new services and new processes about same time. They have not shown any level of competence in offering a service or using process technology that is inimitable by their co mpetitors.

Additionally, it was gathered in the study that although most of the firms engaged in some innovation activities during the reference period, only a few of the firms actually engaged in a broad spectrum of innovation activities. Taken together with the figures on the index of innovation, a main implication of these is that the capability for innovation in the indigenous oil and gas servicing firm in Nigeria is generally low (Tables 1 and 2). Indeed, the figures favour the 
fact that capability for organizational innovation is the most pronounced. It follows, then, that much is still to be done to ensure that innovation capability improves in this sub-sector in the three other areas of innovation considered in this study.

Further empirical evaluation of the intensity of innovation was somewhat difficult to establish at the sub-sectoral level because most of the firms were reluctant to supply precise financial information, particularly regarding their turnover.
Data on machinery/equipment investment was not available from any of the firms.

Table 3. Number of patents request ed by and granted to the firms within the period 2007-2010

\begin{tabular}{cccc}
\hline No. of firms & $\begin{array}{c}\text { No. of patents } \\
\text { requested }\end{array}$ & $\begin{array}{c}\text { No. of patents } \\
\text { granted }\end{array}$ & Intensity \\
\hline 70 & 9 & 2 & 0.03 \\
\hline
\end{tabular}

Source: Field survey, 2011

Table 4. Correlation between number of R\&D staff and the innovation types

\begin{tabular}{|c|c|c|c|}
\hline $\begin{array}{c}\text { No. of people working in R\&D in } \\
\text { the firms in 2007 }\end{array}$ & Product Innovation & Process Innovation & Organisational Innovation \\
\hline $\begin{array}{c}\text { No. of people working in R\&D in } \\
\text { the firms in 2008 }\end{array}$ & -.077 & 0.505 & 0.126 \\
\hline $\begin{array}{c}\text { No. of people working in R\&D in Pearson Correlation } \\
\text { the firms in 2009 }\end{array}$ & -0.030 & 0.505 & 0.126 \\
\hline $\begin{array}{c}\text { No. of people working in R\&D in Pearson Correlation } \\
\text { the firms in 2010 }\end{array}$ & 0.339 & 0.258 & 0.426 \\
\hline
\end{tabular}

**. Correlation is significant at the 0.01 level (2-tailed).

Source: Field Survey, 2011

Table 5. Int ensity of organisational learning among the selected firms

\begin{tabular}{ccccc}
\hline Training programmes held in the firms & 2007 (\%) & 2008 (\%) & 2009 (\%) & $2010(\%)$ \\
\hline ICT & 34.3 & 2.4 & 17.1 & 17.1 \\
Repairs and Maintenance & 5.7 & 14.3 & 34.3 & 32.9 \\
Project Management & 1.4 & 7.1 & 22.9 & 27.1 \\
Technical Report Writing & 0 & 2.9 & 8.6 & 7.1 \\
Industrial Safety & 11.4 & 18.6 & 27.1 & 34.3 \\
\hline
\end{tabular}

Source: Field survey, 2011

Table 6. Impact of innovation on firms' performance

\begin{tabular}{cccc}
\hline Firms' performance & Increased(\%) & Unchanged (\%) & Decreased (\%) \\
\hline Profit & 50.8 & 49.2 & 68.2 \\
Market Share & 31.8 & 69.7 & 60.9 \\
Diversification & 30.3 & 17.2 & 1.6 \\
Product differentiation & 39.1 & 46.8 & 3.2 \\
Process improvement & 81.2 & 61.3 \\
New product development & 53.2 & 35.5 & \\
\hline
\end{tabular}

Source: Field survey, 2011

\section{Conclusions}

The major technological influencers of innovation capability within the sub-sector revolved around training, research and development, and innovation investment and almost all the firms are involved in at less of the three mentioned. As the case studies confirmed, most of the firms operate at sub-optimal capacities due to the exogenous constraints they face. These exogenous constraints are notably poor power supply, weak institutions and very low levels of government support. Besides, one particular factor that seemed to have negatively impacted firm-level 
innovation in the firms surveyed was the very low support available through the knowledge institutions. Nonetheless, the firms apparently make up for this deficiency through the considerable support system available from their trade association which acted as a major avenue of learning and capability building. Together with that, the firms may have interacted most extensively with their competitors, customers, and suppliers.

\section{Strategic Implications for Practice}

For the indigenous firms, the following specific suggestio ns are useful for the build-up of innovation intensity:

i. firms are required to imp rove their absorptive capacities by creating regular programmes for staff development, and making the necessary investments.

ii. firms should make efforts to interact with government, knowledge institutions and other key actors of the sectoral innovation system.

\section{REFERENCES}

[1] Bell, M. and Pavitt, K. (1997), Technological accumulation and industrial growth: contrasts between developed and developing countries. In: Archibugi D. and Michie J. (eds),

[2] Chesbrough, H. (2003), Open Innovation: the new imperative for creating and profiting from technology, Harvard Business School Press

[3] Chesbrough, H., Vanhaverbeke, W. en West, J., eds. (2006), Open Innovation: Researching a New Paradigm, Oxford University Press.

[4] Cohen, W.M. and Levinthal, D.A., 1989. Innovation and learning: the two faces of R\&D. The Economic Journal 99, 569-596.

[5] Egbetokun, A. A., Siyanbola, W. O. and Adeniyi, A. A. (2007). Assessment of Innovation Capability in the Cable and Wire Manufacturing Industry in Nigeria: a case study approach. Paper presented at the Micro Evidence on Innovation in developing Economies[MEIDE], May 31 June 1, 2007, UNU-MERIT, Maastricht, the Netherlands. Available online at: http://www.merit.unu.edu/MEIDE/paper s/2007/egbetokun_siyanbola_adeniyi_assessment \%20 of \%20 innovation \%20 capability...cable \%20 and\%20 wire \%20 manufacturing\%20 industry.pdf[accessed 11 July 2011].

[6] Goedhuys, M. (2007). The impact of innovation activities on productivity and firm growth: evidence from Brazil. UNU-MERIT Working Paper \#2007-02, UNU-MERIT, the Netherlands.

[7] Hamel G. and Prahalad. C.K. (1994). Competing for the future. Harvard Business School Press, Boston p.p.231-232.

[8] Hitt, M., Hoskisson, R., and Nixon, R., (1997). A mid-range theory of interfunctional integration, its antecedents and outcomes. Journal of Engineering and Technology Management, 10, 161-185.
[9] Hitt, M.., Ireland, R.D. and Lee, H. (2000) Technological learning knowledge management, firm growth and performance: an introductory essay', Journal of Engineering and Technology Management, Vol. 17, pp.231-246.

[10] Jegede O.O., Ilori M.O., Siyanbola W.O., Sonibare J.A., Abereijo I.O. (2011). Assessment of Technological innovations in the Indigenous Oil and Gas Servicing Firms in Nigeria. Paper presented at the $9^{\text {th }}$ annual GLOBELICS conference in Buenos Aires, Argentina. Nov 15-17, 2011. Available online at http://www.ungs.edu.ar/globelics/wp-con tent/up loads/2011/12/ID-203-Jejede-Llori-Siy anbola-Soniba re-Abereijo-Learning-and-innov ation-lessons-from-sectorial.pdf

[11] Lall, S., (1991). "Human Resources, Technology and Industrial Development in Sub-Saharan Africa" in Chhiber A. and Stanely F. (eds.), Economic Reform in Sub-Saharan Africa, World Bank, Washington D.C.

[12] Lall, S. (1994) 'The East Asia Miracle Study: Does the Bell Toll for Industrial Strategy?’ World Development 22(4).

[13] Lewanika, M.M. (2006) Centres of excellence: not ideal for African Science and Development Network (SciDev.Net) Opinions, December 2010 (available online at http://www. scidev.net).

[14] OECD (2005). Proposed guidelines for collecting and interpreting technological innovation data: Oslo Manual, 3rd ed. Organisation for Economic Cooperation and Development (OECD). Paris.

[15] Oyelaran-Oyeyinka, B., Laditan, G. O. A. and Esubiyi, A. O. (1996). Industrial innovation in Sub-Saharan Africa: the manufacturing sector in Nigeria. Research Policy 25 (7), 1081-1096

[16] Ozigbo N. C (2008). Technological Capacity Building in the Nigeria's Oil and Gas Industry Proceedings of the 19th Annual International Information Management Association

[17] Polcuch, E. F., Lugones, G. and Peirano, F. (2005). Innovation in Developing Countries: Characteristics and Measurement Priorities In: Micheline Goedhuys (ed.). Technology Policy Briefs, Vol. 4 Issue 1, 2005. United Nations University, Netherlands.

[18] Prusak L. (1996) “The knowledge advantage”, Strategy and Leadership, March-April.

[19] Romijn, H. and Albaladejo, M. (2002). Determinants of innovation capability in small electronics and software firms in southeast England. Research Policy 31 (2002) 1053-1067.

[20] Rosa, J. and Mohnen, M (2008). Knowledge Transfers between Canadian Business Enterprises and Universities: Does Distance Matter? UNU-MERIT Working Paper \# 2008-17. Available at http://www.merit.unu.edu/publications /wppdf/2008/wp2008-017.pdf (Accessed March 21, 2011).

[21] Souitaris, V. (2003). Determinants of technological innovation: Current state of the art, modern research trends and future prospects. In: Shavinina L. V. (ed.), The International Handbook on Innovation. Elsevier Science, Oxford

[22] Tidd, J. (2001). Innovation Management in context: Environment, organization and performance. International Journal of Mnangement Reviews, 3 (3), 169-184. 
[23] Timmer, M. P. (1999). Climbing the Technology Ladder Too Fast? An International Comparison of Productivity in South and East-Asian Manufacturing, 1963-1993. Eindhoven Centre for Innovation Studies (ECIS) Working Paper 99.2, ECIS, The Netherlands

[24] UNIDO (2002). Innovative Technology Transfer Framework
Linked to Trade for UNIDO Action. United Nations Industrial Development Organisation UNIDO, Vienna

[25] UNU-INTECH (2004). Designing a Policy-Relevant Innovation Survey for NEPAD, mimeo: A Study prepared by United Nations University Institute for New Technologies, UNU-INTECH, Maastricht, The Netherlands. 